\title{
"LITTLE COGS OF THE HUGE STATE MACHINE". FORMATION AND DEVELOPMENT OF NURSERY CARE SYSTEM IN 1920-1930s (ON THE MATERIALS OF THE REPUBLIC OF GERMANS IN THE VOLGA REGION)
}

\author{
Lyudmila A. Falaleeva \\ Volgograd State University, Volgograd, Russian Federation
}

\begin{abstract}
The article is devoted to insufficiently studied aspects of the history of the Volga Germans. On the basis of the documents kept in the State Historical Archives of the Volga Germans, the author reveals the peculiarities of formation and development of the nursery care system in the USSR of Volga Germans in 1920-1930s. In the article measures on preparing medical and pedagogical staff are reviewed. It was concluded that the establishment of nurseries led not only to improvement of children's health, but also released labour force of peasant women for the national economy.

The author found that the first information about the opening of nurseries in the German autonomy is related to 1921 - from that moment an active process of formation of the Soviet system of nursery facilities in the region had begun. Due to large-scale famine of the early 1920s, existence of nurseries was under threat, despite the active government policy on this issue. Only in 1925 the matter of protection of motherhood and childhood stabilized, and with active support of female population of Volga Germans started to rapidly gain the momentum. In the mid-1930s more than 5000 children in ASSR NP became pupils of nurseries. All the year round a woman was able to break free from the hassle of taking care of children and the young generation from the first years of life was brought up under state control.

The operation of nurseries caused both a need and an interest among German women, in contrast to many other social projects of the Soviet power against women. The author concludes that the mass distribution of nurseries in the territory of ASSR NP and their introduction into the social environment, allows considering them as significant administrative practices aimed at the destruction of traditional ways of life of women, effective even in the national autonomy.

Key words: Germans of the Volga regions, nurseries, early childhood care, protection of mothering and childhood, ideology, social policy, everyday life.

Citation. Falaleeva L.A. "Little cogs of the huge state machine". Formation and development of nursery care system in 1920-1930s (on the materials of the Republic of Germans in the Volga region). Vestnik Volgogradskogo gosudarstvennogo universiteta. Serija 4, Istorija. Regionovedenie. Mezhdunarodnye otnoshenija [Science Journal of Volgograd State University. History. Area Studies. International Relations], 2017, vol. 22, no. 2, pp. 98-108. (in Russian).
\end{abstract}

\section{«МАЛЕНЬКИЕ ВИНТИКИ ОГРОМНОЙ ГОСУДАРСТВЕННОЙ МАШИНЫ». СТАНОВЛЕНИЕ И РАЗВИТИЕ СИСТЕМЫ ЯСЕЛЬНЫХ УЧРЕЖДЕНИЙ В 1920-1930-е ГОДЫ} (ПО МАТЕРИАЛАМ РЕСПУБЛИКИ НЕМЦЕВ ПОВОЛЖЬЯ)

\author{
Людмила Александровна Фалалеева \\ Волгоградский государственный университет, г. Волгоград, Российская Федерация
}


Аннотация. Статья посвящена малоизученным аспектам истории поволжских немцев. На основе документов, хранящихся в Государственном историческом архиве немцев Поволжья, автор раскрывает особенности становления и развития системы ясельных учреждений в АССР НП в 1920-1930-е годы. Сделан вывод о том, что создание детских яслей должно было не только улучшить состояние здоровья детей, но и высвободить для народного хозяйства рабочие руки крестьянок. Рассмотрены меры по подготовке медицинских и педагогических кадров.

Ключевые слова: немцы Поволжья, ясли, дошкольное воспитание, охрана материнства и детства, идеология, социальная политика, повседневность.

Цитирование. Фалалеева, Л. А. «Маленькие винтики огромной государственной машины». Становление и развитие системы ясельных учреждений в 1920-1930-е годы (по материалам Республики немцев Поволжья) / Л. А. Фалалеева // Вестник Волгоградского государственного университета. Серия 4, История. Регионоведение. Международные отношения. -2017. - Т. 22, № 2. - С. 98-108.

Сегодня часто можно прочесть в публикациях, что революционные события 1917 г. в России принесли женщинам широкую свободу и равноправие, принудительно разорвав оковы традиционного отношения к их роли в семье и обществе. Сложившийся стереотип формирует поверхностное представление о влиянии мероприятий первых десятилетий советской власти на повседневную жизнь женщин. В свете доступности новых источников и разнообразия методологических концепций, этот вопрос представляется более глубоким и противоречивым, а потому требует детального исследования, прежде всего, с учетом многонациональных особенностей населения нашей страны.

Практически единогласно специалисты в области советской социальной и гендерной истории выделяют охрану материнства и детства как основное направление в решении женского вопроса. Материнство рассматривалось как важная социальная функция женщины, дающей государству в лице своего ребенка нового гражданина, чья жизнь и здоровье являются непременным условием экономического и культурного процветания страны. Так материнство превращалось в общественно полезный труд, требующий условий для его выполнения. Соблюдение таких условий обеспечивала созданная государством система охраны материнства и детства. Иными словами, она представляла собой комплекс государственных и общественных мероприятий, направленных на обеспечение здоровья матери и ребенка, укрепление семьи, поощрение материнства, создание наиболее благоприятных условий для воспитания детей, их физического, интеллектуального и нравственного развития. К этим учреждениям относились дома матери и ребенка, дома ребенка, детские дома, ясли, детские консультации, молочные кухни [20]. Среди перечисленных учреждений особое место занимали ясли. Во-первых, как средство освобождения женщин от семейных обязанностей в пользу строительства социалистического будущего. Во-вторых, как способ внедрения нового педагогического подхода, насыщенного марксистсколенинской идеологией, вытеснившего традиционное домашнее воспитание. В-третьих, как комплекс мер, направленных на обеспечение физического здоровья поколений.

Поэтому интерес представляют как исследования по истории возникновения и развития ясельных учреждений в России, так и в целом характеризующие социальный статус семьи и женщины. Отметим работы, вышедшие в последнее десятилетие: Ю. Градсковой [9], П.П. Котова и В.А. Пилипенко [19], С.В. Голиковой [8], Г.Г. Гниятуллиной [7], Е.В. Колгановой [18], С.А. Бочан [1], В.Н. Ракачева [26]. Авторы, основываясь преимущественно на региональном материале, а также теоретических воззрениях советской политической элиты, характеризуют специфику учреждений охраны материнства и детства в СССР. Проблеме социально-политического и экономического положения женщин в немецкой автономии посвящено диссертационное исследование Ю.А. Морозовой [22]. Автору удалось частично отразить социальные меры, направленные на улучшение положения женщин, занятых в производстве. Однако вопросы относительно множества аспектов работы детских яслей в регионе остаются по-прежнему не раскрытыми. 


\section{ОТЕЧЕСТВЕННАЯ ИСТОРИЯ}

В начале 1920-х гг. в Трудовой коммуне Области немцев Поволжья, по причине масштабного голода, существование яслей находилось под угрозой, несмотря на активную политику государства в этом вопросе. К 1922 г. по области количество детей ясельного возраста достигало 7800 чел., из них сирот 558 чел., полусирот (с одним родителем) 556 чел., бесприютных 548 чел. [14, л. 1]. В целом 1920 1930-е гг. - это период активного формирования советской системы ясельных учреждений. Выясним его особенности на примере АССР НП. Для этого обратимся к документам фондов отдела здравоохранения ${ }^{1}$ и Наркомата здравоохранения АССР НП ${ }^{2}$, хранящимся в Государственном историческом архиве немцев Поволжья в г. Энгельсе (далее - ГИА НП). В рассматриваемый период организация яслей была возложена на учреждения здравоохранения. Такое положение было обусловлено последствиями масштабного голодного бедствия в регионе, высокой детской смертностью, распространением инфекционных заболеваний, низким уровнем гигиены матери и ребенка.

Новое руководство страны прекрасно понимало ценность социального ресурса не только в лице рабочих и крестьян, но и в лице женщин и даже детей. Имея представления о реальных потребностях женского населения, большевистское правительство использовало, с одной стороны, мощную социальную опеку, с другой - стратегию популизма для манипуляции общественным сознанием. Это позволяло массово привлекать женщин к социалистическому строительству. В 1923 г. на XII съезде РКП(б) было принято постановление вовлекать работниц и крестьянок в партийное, советское, профессиональное и кооперативное строительство в первую очередь через улучшение быта работниц. При этом фактическое обеспечение бытовых условий возлагалось на самих женщин посредством участия в профессиональных и кооперативных союзах, женотделах и делегатских собраниях [27, с. 724]. Общественные организации содействовали коллективному сплочению и развивали женскую инициативу. Такой подход одновременно фокусировал внимание женщин на злободневных вопросах и предлагал возможность для их самостоятельного решения, но при одном условии - исключительно в контексте стратегии большевиков. Таким образом, женщины становились активными участниками реализации политики партии. Говоря иначе, контроль над потребностями женского населения и деятельность по их реализации становились значимым аспектом государственной политики в отношении женского вопpoca. Если в обществе по-прежнему прочно довлела установка о второстепенной роли женщины, то большевистская пропаганда, напротив, подчеркивала ее высокий статус и социальную роль.

Из обобщенного доклада отдела здравоохранения Немкоммуны и частных докладов заведующих яслями мы узнаем о реальном состоянии местных детских учреждений в начале 1920-х годов. Общая численность населения Области немцев Поволжья, до вступления в силу декрета об «округлении» ${ }^{3}$, составляла около 400 тыс. человек [6, с. 279]. Дети до 3 лет потенциально входили в категорию воспитанников яслей. По данным на январь 1922 г. в области имелось 10 яслей смешанного типа, одни открытого типа и один приемник для сирот закрытого типа. Все перечисленные учреждения приходились на 7,8 тыс. детей ясельного возраста. Количество детей в разы превышало ресурсы, предназначенные для обеспечения коллективного воспитания. К тому же, ни в одном из организованных учреждений не хватало даже самого необходимого: качественного питания, посуды, мебели, белья, мыла [14, л. 1]. На примере отдельных яслей выясним, что сотрудники отдела здравоохранения трактовали как недостаток хозяйственно-материального обеспечения. В яслях с. Паульское отсутствовало белье для оборудования спальных мест и соблюдения гигиены. «Матрацы, которые получены не матрацы, а четырехугольные наволочки. Их нужно перешить по размеру кроваток, а ниток не имеется. <...> Ввиду того, что не имеется отдельных, особых, обеденных фартучков, также наблюдается большая неаккуратность при обеде детей $<. .>$ Они пачкаются при обеде и такими грязными должны идти домой. Ведь нет возможности стирать единственно имеющееся платье. Хотя дети здесь и моются, даже купаются, но одевать их в чистое не возможно» $[11$, л. 3$]$. За- 
ведующая яслями в с. Боаро, т. Меркер, перечисляет инвентарь, в котором остро нуждались сотрудники и воспитанники: «миски, лопата, котел, кисть, ножи, вилки, сковорода, посуда для детей» $[4$, л. 4]. Это не позволяло обеспечить должного ухода за детьми, провоцировало антисанитарию и заболевания. К тому же, после двух лет недорода, в 19201921 гг. в ясли поступали отощавшие или слабые от рождения дети. Но продуктов на то, чтобы оздоровить их, в яслях не было.

Рацион новорожденных состоял преимущественно из блюд на основе растительного масла, солонины, ржаной муки и пшена. Поэтому из яслей регулярно поступали сведения о распространении кишечных болезней у детей $[14$, л. 1]. Холод провоцировал легочные заболевания - документально зафиксированы случаи, когда помещения не отапливались по 2-3 дня в сезон, когда это было необходимо. Ни в одних яслях не было аптечек, даже с самыми необходимыми медикаментами [15, л. 57]. Причину столь бедственного положения стоит искать в первую очередь в общей хозяйственно-экономической ситуации в стране. В условиях новой экономической политики государственные ресурсы на обеспечение детских учреждений сокращались, обязанности снабжения переходили на местный бюджет [15, л. 57].

Руководители детских учреждений старались справляться с нуждой, буквально на пустом месте изыскивая средства на приобретение продуктов. Заведующий детскими яслями села Грязноватка организовал неделю сбора пожертвований в пользу детских учреждений, но результат предприятия был предсказуемо мал, поскольку обедневшее население не имело возможности совершить даже малое подаяние. Предвидя такой расклад, заведующий организовал запашку земельных участков в двух селах по 4 десятины, подготавливая почву для будущих посевов в пользу яслей [3, л. 9].

Организация яслей поручалась женщинам без специального медицинского и педагогического образования, но обладавшим желанием и опытом в уходе за детьми, часто из многодетных семей. На эту работу их делегировали сельские женские отделы и комитеты, но она не являлась исключительно женской сферой деятельности, нередко мужчины являлись заведующими яслями. Непосредственной работой с детьми занимались исключительно женщины. Доклады женщин-руководителей отличаются эмоциональными комментариями, наполненными болью за свое дело. Заведующая детскими яслями с. Паульское с досадой писала в отдел здравоохранения: «Вообще моими яслями я очень недовольна. Надеюсь, что в будущем устрою так, как полагается». В ее понимании детские ясли должны быть по-домашнему уютными, где ребенок не будет испытывать и малейшей нужды - он будет одет, обут и накормлен досыта, окружен всеми удобствами, занят играми и сможет развиваться творчески [11, л. 3 об.].

Сотрудники яслей добросовестно выполняли свою работу в интересах детей и их матерей. В яслях выдавали на дом обеды и ужины для тех, кто не мог присутствовать в группе. В докладе отмечено, что детей до 3 лет с трудом приводили в ясли, вместо них туда гораздо охотнее отправляли детей пятилетнего возраста [11, л. 3]. Таким образом, фактическими воспитанниками в первые годы работы яслей становились не только и не столько дети установленной возрастной группы, а их старшие братья и сестры. Это явление противоречило основному предназначению яслей, однако случаев наказания по фактам нарушений в документах не отражено. По причине сильного истощения не все дети могли посещать ясли, поэтому практика выдачи питания на дом была характерна для большинства детских учреждений автономии. В некоторых яслях сотрудники изыскивали возможность оставлять на проживание детей-сирот, обеспечивая необходимый уход [23, л. 4].

Типичный состав персонала был небольшим: заведующая, по 1-2 воспитательницы и няни, охранник и кухарка на группу около 30 детей, 8-9 чел. всего приходилось на группу в 50 детей, штатные врачи отсутствовали. Из-за низкого материального обеспечения, недостатка помещений и оборудования организация детских яслей являлась сложным мероприятием. Отдел охраны материнства и младенчества НКЗ и отдел по работе среди женщин, занимавшийся главным образом пропагандистской работой, посредством циркуляров рекомендовали расширять и углублять 
сеть детских учреждений на местах [5, л. 65]. Однако финансирование в регионах, подвергшихся голоду, в основном ложилось на плечи местного населения, низовых административных органов, которым предоставлялось право устанавливать натуральную повинность с каждого двора на содержание детей в яслях. Часть средств поступала через крестьянские комитеты взаимопомощи, совхозы и кооперативы. Сбор средств и организация детских яслей отделом охраны материнства и младенчества проводились как широкая кампания, в обязательном порядке в сотрудничестве с женотделами, акции приурочивались к международному дню работниц [30, л. 14].

В летнее время малыши большую часть времени проводили на улице без должного родительского присмотра. Это приводило к несчастным случаям, дети погибали по собственной несознательности или халатности взрослых [17, с. 77]. В яслях же они находились под присмотром, их увлекали развивающими играми, кормили. Смертельные случаи в детских яслях были крайней редкостью. В докладе отдела охраны материнства и младенчества отмечено отношение населения к открытым летом 1925 г. сезонным детским яслям в самых беднейших селах республики. На большинство батрачек, вынужденных уезжать на заработки и бросать детей на произвол судьбы, открытие яслей произвело несравнимое впечатление! Женщины приходили на общественные собрания, чтобы публично высказать благодарность и поддержать начатое дело [13, л. 154]. В целом внедрение мероприятий по охране материнства и младенчества встречало поддержку со стороны женщин немецкой автономии. Под ними подразумевалась не только организация детских яслей, но и правовая поддержка женщин, содействие профессиональной подготовке для работы в детских учреждениях, культурно-просветительская работа и т. п.

Всем ли желающим была доступна возможность определить ребенка в ясельную группу? Отнюдь. Для матерей, желавших отправить детей в ясли, существовали определенные правила, соответствие которым было обязательным требованием. В ясли оформляли наиболее нуждающихся детей с двухмесячного и до трехлетнего возраста, матери ко- торых работали на государственных предприятиях и учреждениях и состояли в профсоюзах. Нуждающимися считались те дети, чьим матерям на время службы не с кем было оставить их дома. Прием в ясли проводился в порядке очередной записи, составляемой участковым врачом [24, л. 4]. Такая практика относилась к женщинам, проживавшим в крупных населенных пунктах. Что же касается женщин-крестьянок, то среди них приоритет отдавался активисткам государственных и общественных организаций, а также колхозницам.

Финансовый и продовольственный кризис начала 1920-х гг. ставил под вопрос возможность функционирования учреждений охраны материнства и младенчества в регионе. В материалах фонда отдела здравоохранения автономной Области немцев Поволжья первые сведения об открытых детских яслях относятся к 1921 году. В 1923 г. деятельность отдела в основном свелась к работе с приютами, прочая, даже культурно-просветительская работа, отсутствовала. Взаимодействие с губернским отделом народного образования, в чье ведомство передавались дети старше трехлетнего возраста, а также отделом по ликвидации последствий голода, занимавшимся вопросами улучшения детского питания, женотделами было крайне редким и не приносило конкретных результатов. Связь областного отдела здравоохранения с местными организациями, в том числе с яслями, носила регулярный характер через письма и живой диалог. Однако из-за отсутствия средств заведующая областным отделом Охраны материнства и младенчества не имела возможности лично осуществлять проверку учреждений в селах, что фактически вело к безграничным полномочиям заведующих детскими яслями на местах: от решения организационных до воспитательных вопросов. По сравнению с 1922 г. в 1923 г. количество яслей сократилось до 5. Работу продолжали только 4 учреждения смешанного типа, одно открытого типа, 3 учреждения закрытого типа [15, л. 57]. Под закрытым типом понимались дома ребенка, они предназначались для воспитания детей сирот до 3-летнего возраста, а также детей одиноких матерей [21, с. 172]. Иных детских учреждений под ведомством отдела 
не было. Государственное снабжение обеспечивало только 20 \% необходимых средств и распределялось равномерно среди учреждений [15, л. 57-58; 13, л. 150]. Обеспечивать детей завтраками, а иногда и бельем и обувью помогали иностранные гуманитарные миссии. Весомый вклад в спасение жизней голодавших детей региона внесла Американская администрация помощи (см. подробнее [29]).

Только к 1925 г. дело охраны материнства и младенчества стабилизировалось. Отдел подчинялся народному комиссариату здравоохранения АССР НП, расширился спектр деятельности. В его состав входили заведующий и врач-инструктор. Инструктор имел врачебный стаж педиатра и дополнительную стажировку в институте Охраны материнства и младенчества. Важную роль в постановке массового детского воспитания играл персонал детских учреждений. Однако большинство сотрудников, как и прежде, не имело должного образования. Профессионалы-воспитатели отсутствовали, так как для их подготовки в регионе не было условий. Это подтверждает циркулярное письмо отдела Охраны материнства и младенчества немецкой автономии, где в красках расписана высокая значимость и необходимость квалифицированных сестер-воспитательниц [31, л. 76-76 об.]. Чтобы хоть как-то повысить квалификацию сотрудников, стали предприниматься попытки организовать местные курсы для сестер-воспитательниц сроком на 2-3 месяца. В качестве целевой аудитории выступали уже работающие сестры-воспитательницы и женщины, желавшие посвятить себя этой деятельности [12, л. 112]. Но впервые открыть курсы удалось только спустя 3 года, в 1928 году.

Во время торжественного открытия перед 18 девушками, курсантками первого набоpa, с напутственными речами выступили руководители отделов Народного комиссариата здравоохранения Немреспублики. Заведующая отделом охраны материнства и младенчества т. Вишневская так охарактеризовала миссию поступивших на обучение: «На Вас, работницы и крестьянки, возлагается огромная задача распространять на местах приобретенные на этих курсах знания в гущу крестьянского населения и вернуться домой достаточно подго- товленными для этой ответственной задачи. Вы представляете из себя отдельные маленькие винтики огромной государственной машины. Поэтому вы должны отнестись к учебе с достаточной серьезностью, дабы оправдать возлагаемые на Вас надежды» [25, л. 8]. Высокопарная речь подчеркивает понимание руководством сопричастности «маленького человека» к значимым государственным процессам, в частности, роль сотрудников яслей на местах, а также общее значение системы ясельных учреждений в АССР НП.

Отсутствие профессиональной подготовки работников детских яслей не сказывалось пагубно на качестве ухода за детьми. Гораздо больше оно влияло на идеологическую составляющую воспитательного процесса. Женщины вели коллективное воспитание на понятном и доступном для себя уровне, в русле национальных традиций, отстраненно от «идеологического пресса». Это подтверждают слова руководителей наркомата здравоохранения, по долгу своей работы имевших опыт посещения детских учреждений Москвы и Ленинграда. Сравнивая уровень столичных и местных детских учреждений, они пришли к выводу, что дети, воспитывавшиеся в Немреспублике, по поведению и развитию оказались гораздо больше приближены к детям семьи, так как воспитывались на типичный семейный немецкий лад, а не по госпитальному образцу. Важной составляющей воспитательного процесса, по мнению т. Вишневской, являлось дружественное взаимоотношение, отсутствие ссор и раздоров как основная особенность в коллективах воспитанников. Дети преимущественно росли коммуникабельные, любознательные, осваивали массу игр, песен на русском и немецком языках [13, л. 151].

О востребованности работы учреждений охраны материнства и младенчества среди населения говорят материалы архивных дел. Значимым показателем являются сведения об их перегруженности в 1,5-2 раза, отказы в приеме при обращении, так что спрос на место в яслях в 5 раз превышал предложение [2, л. 186]. Начиная с 1925 г. при активной поддержке женского населения Немреспублики дело охраны материнства и младенчества стремительно набирало обороты. В середине 1930-х гг. около 5000 детей АССР НП было 
охвачено яслями только в зимний период [16, л. 41], в летний же период их численность стабильно увеличивалась в связи с сезонными полевыми работами крестьян. Приведенные цифры свидетельствуют об успешной реализации государственной политики в системе социального воспитания. Теперь круглый год женщина имела возможность освободиться от хлопот по уходу за детьми, а юное поколение с первых лет жизни воспитывалось под государственным контролем. Работа яслей вызывала одновременно потребность и интерес среди немецких женщин, в отличие от многих других социальных проектов советской власти в отношении женщин.

Постепенно, освобождаемая от необходимости полного детского воспитания, посредством разветвленной сети государственных и общественных организаций, повседневная жизнь женщин наполнялась новым содержанием. Во-первых, женщин активно вовлекали в тяжелый производственный труд. В колхозных бригадах они работали не только доярками, но и вели уход за скотом, осваивали трактора, paботали на молотильном току и т. п. Во-вторых, политико-просветительская работа среди женщин стала одним из приоритетных направлений политики советского правительства, занятия приобретали массовый и обязательный характер. Новые тенденции противоречили устоявшемуся образу жизни немецких семей, численно преобладавших в автономии.

Повседневный уклад жизни немцев в Поволжье формировался под влиянием религии. Основой веры являлась христианская традиция, согласно которой положение женщины определялось при ее мужчине. Кроткая и покорная она являлась надежным тылом, обеспечивающим продолжение рода, укрепление традиций, воспитание детей в интересах общины. Ярким примером является свадебная традиция гернгутеров, сохранявшаяся вплоть до середины XIX века. Согласно ей имена брачующихся определял жребий. Я. Дитц в начале XX в., описывая историю поволжских немцев-колонистов, охарактеризовал статус женщины не иначе как «раба своего мужа» - она подвергалась жестоким побоям и не имела голоса в общем хозяйственном распоряжении. При этом женская работа по дому вдвое превышала мужскую. Кроме того, на женщину возлагалась обязанность воспитания детей в религиозном духе, общественные же занятия, не относящиеся к нуждам общины, считались излишними [10, с. 380$]$. В свою очередь, воспитанные в религиозной традиции немцы-мужчины, как правило, были надежными семьянинами: отвечали за обеспечение семьи и принимали участие в воспитании детей, особенно мальчиков [28, с. 254,261$]$. Таким образом, немецкие семьи представляли собою органичный союз партнеров, действующих в общих интересах на благо продолжения рода и развития общины. Несмотря на доминирующую роль мужчины, женщина-мать и хозяйка была почитаема членами семьи. Именно она обучала детей религии и языку, прививала духовные ценности.

Социальный конфликт, вызванный переоценкой общественной роли женщины, заключался в отсутствии для женщины возможности выбора в самореализации. Все, что противоречило интересам власти, критиковалось на публичных собраниях, контролировалось и пресекалось общественными организациями, партийными и государственными органами. Духовнорелигиозные потребности и вовсе попадали под уголовное преследование. Реальные интересы и потребности женщин в сфере здравоохранения и образования к концу 1930-х гг. были под тотальным контролем коммунистической партии. Женская активность поощрялась исключительно в русле социалистического труда, коммунистического воспитания детей, общественной деятельности. Массовое распространение детских яслей на территории АССР НП и внедрение их в социальную среду позволяет говорить о них как о значимой административной практике, направленной на разрушение традиционного образа жизни женщины, эффективной даже в условиях национальной автономии.

\section{ПРИМЕЧАНИЯ}

${ }^{1}$ После событий октября 1917 г. организация новой системы постоянных органов здравоохранения началась с мест. В составе исполкомов губернских, уездных и городских Советов создавались медико-санитарные отделы (с образованием Наркомздрава они получили общее название отделов здравоохранения). На основании декрета СНК от 18 июля 1918 г. было принято постановление об организации Губернского Медико-санитарного 
отдела при Саратовском Совете рабочих, крестьянских и красноармейских депутатов. 15 августа 1918 г. был образован уездный отдел здравоохранения с центром в Екатериненштадте (областным он стал называться с образованием Трудовой Коммуны Области немцев Поволжья осенью 1918 г.). В 1921 г. Областной отдел здравоохранения имел 10 подотделов, в том числе отдел охраны материнства и младенчества. В его обязанности входила забота о матерях и младенцах посредством яслей и консультаций. В 1923 г. в ведении отдела здравоохранения, помимо прочих учреждений, находились 2 родильных приюта, 1 детская лечебница, 5 детских яслей. Среди медицинского персонала насчитывалось 48 фельдшеров-акушеров. За время деятельности Областного отдела здравоохранения переименований не было. С ликвидацией Трудовой Коммуны Области немцев Поволжья был ликвидирован и областной отдел здравоохранения. См.: ГИАНП. Ф. Р-851. Оп. 1. Предисловие. Л. 19.

2 В январе 1924 г. в связи с преобразованием Области Немцев Поволжья, наряду с другими Наркоматами был образован и Народный Комиссариат Здравоохранения Республики. Он являлся центральным медицинским органом, руководившим всем медикосанитарным делом АССР НП, подчинялся в своей деятельности Центральному исполнительному комитету, его Президиуму, Совету Народных Комиссаров АССР НП и Народному Комиссариату Здравоохранения РСФСР. Этот орган государственной власти обладал распорядительными полномочиями и выполнял контролирующие функции, а также регулировал деятельность медицинских учреждений, расположенных на территории АССР НП. Наркомат здравоохранения занимался разработкой научных и научно-практических вопросов в области здравоохранения. С 1924 по 1938 г. в его структуру наравне с прочими входили отдел охраны здоровья детей и отдел охраны материнства и младенчества. В 1938 г. структура Комиссариата здравоохранения имела управления и сектора. Управление охраны матери и ребенка руководило женскими и детскими консультациями и роддомами, работой детских садов и домов ребенка. Наркомздрав АССР НП ликвидирован 28 августа 1941 г. на основании Указа Президиума Верховного Совета СССР. См.: ГИАНП. Ф. Р-975. Оп. 1. Предисловие. Л. 1-12.

322 июня 1922 г. ВЦИК РСФСР издал специальный декрет об «округлении» Области немцев Поволжья. В результате территория выросла на $39 \%$, достигнув 25,7 тыс. кв. км, население увеличилось до 527,8 тыс. человек. Процентный состав населения выражался следующим образом: немцев $-67,5 \%$, русских - 21,1\%, украинцев - 9,7\%, других $-1,7 \%$, то есть область стала многонациональной, немецкое население составляло две трети всего населения [6, с. 282].

\section{СПИСОК ЛИТЕРАТУРЫ}

1. Бочан, С. А. Семейно-бытовые новации в сельском социуме 1920-х гг. / С. А. Бочан // Вестн. Ленингр. гос. ун-та им. А.С. Пушкина. - 2014. № 4. - С. 76-81.

2. В неурожайную комиссию при ЦИКе АССР НП сведения о летней ясельной компании за 1925 г. // Государственный исторический архив немцев Поволжья (далее - ГИА НП). - Ф. Р-975. Наркомат здравоохранения АССР НП. - Оп. 1. - Д. 40.

3. В отдел здравоохранения области немцев Поволжья. Входящий № 506. 29 января 1923 г. // ГИА НП. - Ф. Р-851. Областной отдел здравоохранения в г. Энгельсе. - Оп. 1. - Д. 153.

4. В отдел охраны материнства и младенчества «Обздравотдела». Заведующая детяслями села Боаро Меркер Я. К. Доклад. 1922 г. // ГИА НП. Ф. Р-851.- ОП. 1.- Д. 105.

5. Всем Губ. и Обздравотделам. Наркомздравам союзных и автономных республик о летней ясельной кампании. Копия. Циркулярно. 1925 г. // ГИА НП. - Ф. Р-975. - Оп. 1. - Д. 40.

6. Герман, А. А. История немцев России : учеб. пособие / А. А. Герман, Т. С. Иларионова, И. Р. Плеве. - М. : МСНК-пресс, 2005. - 542 с.

7. Гниятуллина, Г. Г. Проблемы охраны материнства и младенчества в Башкирской АССР в 1920-х годах / Г. Г. Гниятуллина // Вестн. ЧелГУ. 2014. - № 8 (337). История. Вып. 59. - С. 25-29.

8. Голикова, С. В. Семья и... Ясли. Страница предыстории / С. В. Голикова // Диалог со временем. Спец. вып. № 23 : Брак и семья в контексте гендерной истории / ред. Л. П. Репина. - М. : Изд-во ЛКИ, 2008. - С. 319-330.

9. Градскова, Ю. Культурность, гигиена и гендер: советизация «материнства» в России в 19201930-е годы / Ю. Градскова // Советская социальная политика 1920-1930-х годов: идеология и повседневность / под ред. П. Романова и Е. Ярской-Смирновой. -М. : ООО «Вариант» : ЦСПГИ, 2007. - С. 242-262.

10. Дитц, Я. Е. История поволжских немцев-колонистов / Я. Е. Дитц. - М. : ГОТИКА, 1997. - 496 с.

11. Доклад заведующей яслями с. Паульское за октябрь месяц. 1921 г. // ГИА НП. - Ф. Р-851. Оп. 1. -Д. 105.

12. Доклад о деятельности отдела Охраны материнства и младенчества Народного комиссариата здравоохранения АССРП. 1925 г. // ГИА НП. Ф. Р-975. - Оп. 1. - Д. 40.

13. Доклад о деятельности отдела Охраны материнства и младенчества Народного комиссариата здравоохранения Немреспублики // ГИА НП. Ф. Р-975. - Оп. 1. - Д. 40.

14. Доклад о состоянии детских лечебных учреждений п/отдела Охраны материнства и младен- 
чества областного отдела здравоохранения Немкоммуны. 1922 г. // ГИА НП. - Ф. Р-851. - Оп. 1. - Д. 153.

15. Доклад п/отдела Охраны материнства и младенчества областного отдела здравоохранения Немкоммуны. 1923 г.// ГИАНП.-Ф. Р-851.-Оп. 1. - Д. 153.

16. Закрепление яслей на зиму 1933-1934 г. // ГИА НП. - Ф. Р-975. - ОП. 1. - Д. 233.

17. Калинина, О. С. Проблемы детского здоровья и гигиены у поволжских немцев Камышинского уезда Саратовской губернии в начале XX в. / О. С. Калинина // Клио. - 2012. -№6 (66). -С. 77-80.

18. Колганова, Е. В. Зарождение системы охраны материнства и младенчества в России в начале XX в. / Е. В. Колганова // Вестн. Моск. ун-та. Сер. 8, История. - 2011. - № 6. - С. 37-50.

19. Котов, П. П. Становление системы ясельных учреждений в Коми АССР в 1920-1930-х годах / П. П. Котов, В. А. Пилипенко // Февральские чтения. Региональная научно-практическая конференция, посвященная 55-летию высшего профессионального лесного образования в Республике Коми (Сыктывкар, 27-28 февраля 2007 г.) : сб. материалов. / ред. Н. А. Юшкова. - Сыктывкар, 2007. - С. 253-256.

20. Краткая медицинская энциклопедия : в 3 т. / гл. ред. Б. В. Петровский. - 2-е изд. - М. : Сов. энцикл., 1989.

21. Мокиенко, В. М. Толковый словарь языка Совдепии / В. М. Мокиенко, Т. Г. Никитина. - СПб. : Фолио-Пресс, 1998. - 700 с.

22. Морозова, Ю. А. Женщины в общественно-политической и экономической жизни немецкой автономии (1918-1941 гг.) : дис. ... канд. ист. наук : 07.00.02 / Морозова Юлия Александровна. - Саратов, 2002. $-213 \mathrm{c}$.

23. П/отделу Охраны материнства и младенчества областного отдела здравоохранения. Заведующая детскими яслями Меркер. Доклад. 31 января 1922 г. // ГИА НП. - Ф. Р-851. - Оп. 1. - Д. 105.

24. Правила для матерей, помещающих детей в ясли. 1922 г. // ГИА НП. -Ф. Р-851. -Оп. 1. - Д. 153.

25. Протокол торжественного открытия курсов по подготовке работников летних сельских ясель. 3 мая 1928 г. // ГИА НП. - Ф. Р-975. - ОП. 1. - Д. 166.

26. Ракачев, В. Н. Советская семья в 1920 1930-е гг.: эксперименты в области социального конструирования / В. Н. Ракачев // Материнство и отцовство сквозь призму времени и культур : материалы Девятой международной научной конференции РАИЖИ и ИЭА РАН (Смоленск, 1316 октября 2016 г.) : в 2 т. / отв. ред. Н. Л. Пушкарева, Н. А. Мицюк. - Смоленск ; М. : Изд-во СмолГУ : ИЭА РАН, 2016. - Т. 1.- С. 74-77.

27. Резолюции и постановления съезда о работе РКП среди работниц и крестьянок // XII съезд РКП(б) 17-25 апреля 1923 г. Стенографический отчет. - М., 1968.
28. Смирнова, Т. Б. Этнография российских немцев / Т. Б. Смирнова. - М. : МСНК-пресс, 2012. - 315 с.

29. Фалалеева, Л. А. Деятельность Американской администрации помощи на территории Царицынской губернии во время голода 1920-х годов / Л. А. Фалалеева // Americana. Вып. 14. Страны Cеверной Америки и война : сб. ст. $=$ North American Nations and War : coll. of art. - Волгоград : Изд-во ВолГУ, 2014. - С. 120-134.

30. Циркулярно. Всем губернским п/отделам Охраны материнства и младенчества и женотделам губернских комитетов. 1922 г. // ГИА НП. Ф. Р-851. - Оп. 1. - Д. 93.

31. Циркулярное письмо областному отделу здравоохранения Немкоммуны. 1923 г. // ГИА НП. Ф. Р-851. - Оп. 1. - Д. 153.

\section{REFERENCES}

1. Bochan S.A. Semeyno-bytovye novatsii v selskom sotsiume 1920-kh gg. [Domestic Innovations in the Rural Society of the 1920s]. Vestnik Leningradskogo gosudarstvennogo universiteta im. A.S. Pushkina, 2014, no. 4, pp. 76-81.

2. V neurozhaynuyu komissiyu pri TsIKe ASSR NP svedeniya o letney yaselnoy kompanii za $1925 \mathrm{~g}$. [To the Crop Failure Commission at the USSR of Volga Germans' Central Executive Committee: Information about the Summer Nursery Company for 1925]. Gosudarstvennyy istoricheskiy arkhiv nemtsev Povolzhya [State Historical archive of the Volga Germans], F. P-975, People's Commissariat of Health of the Autonomous Soviet Socialist Republic of the Volga Germans], Op. 1, D. 40.

3. V otdel zdravookhraneniya oblasti nemtsev Povolzhya. Vkhodyashchiy № 506. 29 yanvarya 1923 g. [To the Healthcare Department of the Administration of Volga Germans. Incoming no. 506. January 29, 1923]. Gosudarstvennyy istoricheskiy arkhiv nemtsev Povolzhya [State Historical Archive of the Volga Germans], F. P-851. Regional Healthcare Department in the City of Engels. Op. 1, D. 153.

4. V otdel okhrany materinstva i mladenchestva «Obzdravotdela». Zaveduyushchaya detskimi yaslyami sela Boaro Merker Ya. K. Doklad. 1922 g. [To the Department of Protection of Maternity and Infancy of the Regional Healthcare Department "Obzdravotdel". Head of the Village Nursery, J.K. Boaro Merker. Report. 1922]. Gosudarstvennyy istoricheskiy arkhiv nemtsev Povolzhya [State Historical Archive of the Volga Germans], F. P-851, Op. 1, D. 105.

5. Vsem Gub. i Obzdravotdelam. Narkomzdravam soyuznykh i avtonomnykh respublik o letney yaselnoy kampanii. Kopiya. Tsirkulyarno. 1925 g. [To All Provincial and Regional Health Departments. To the 
Peoples' Commissariats of Healthcare of Union and Autonomous Republics about Summer Nursery Campaign. A Copy. Circular Letter. 1925]. Gosudarstvennyy istoricheskiy arkhiv nemtsev Povolzhya [State Historical Archive of the Volga Germans], F. P-975, Op. 1, D. 40.

6. German A.A., Ilarionova T.S., Pleve I.R. Istoriya nemtsev Rossii: Uchebnoe posobie [The History of Russian Germans: Tutorial]. Moscow, MSNK-Press, 2005. 542 p.

7. Gniyatullina G.G. Problemy okhrany materinstva i mladenchestva $v$ Bashkirskoy ASSR v 1920-kh godakh [The Issues of Maternity and Infancy Protection in Bashskir ASSR in the 1920s]. Vestnik Chelyabinskogo gosudarstvennogo universiteta, 2014, no. 8(337), iss. 59, pp. 25-29.

8. Golikova S.V. Semya i ... Yasli. Stranitsa predystorii [Family and ... Nursery: Prehistory Page]. Repina L.P., ed. Dialog so vremenem. 23. Spetsialnyy vypusk: Brak $i$ semya $v$ kontekste gendernoy istorii [Dialogue with Time. 23. Special Issue: Marriage and Family in the Context of Gender History]. Moscow, LKI Publishers, 2008, pp. 319-330.

9. Gradskova Yu. Kulturnost, gigiena i gender: sovetizatsiya «materinstva» v Rossii v 1920-1930-e gody [Level of Culture, Hygiene and Gender: Sovietization of Motherhood in Russia in the 1920s-1930s]. Romanov P., Yarskaya-Smirnova E. Sovetskaya sotsialnaya politika 1920-1930-kh godov: ideologiya i povsednevnost [Soviet Social Policy in the 1920s-1930s: Ideology and Everyday Life]. Moscow, Variant Publ.; TsSPGI Publ., 2007, pp. 242-262.

10. Ditts Ya.E. Istoriya povolzhskikh nemtsevkolonistov [The History of Volga Germans-Colonists]. Moscow, GOTIKA Publ., 1997. 496 p.

11. Doklad zaveduyushchey yaslyami s. Paulskoe za oktyabr mesyats. 1921 g. [The Report by Head of Nursery of Paulskoe Village for October. 1921]. Gosudarstvennyy istoricheskiy arkhiv nemtsev Povolzhya [State Historical Archive of the Volga Germans], F. R-851, Op. 1, D. 105.

12. Doklad o deyatelnosti otdela Okhrany materinstva i mladenchestva Narodnogo komissariata zdravookhraneniya ASSRP. 1925 g. [Report on the Activity of the Department of Protection of Maternity and Infancy of the People's Commissariat of Healthcare in the ASSR of Volga Germans. 1925]. Gosudarstvennyy istoricheskiy arkhiv nemtsev Povolzhya [State Historical Archive of the Volga Germans], F. R-975, Op. 1, D. 40.

13. Doklad o deyatelnosti Okhrany materinstva i mladenchestva Narodnogo komissariata zdravookhraneniya Nemrespubliki [Report on the Activities of the Protection of Maternity and Infancy of the People's Commissariat of Healthcare of Volga Germans' Republic]. Gosudarstvennyy istoricheskiy arkhiv nemtsev Povolzhya [State Historical Archive of the Volga Germans], F. P-975, Op. 1, D. 40.

14. Doklad o sostoyanii detskikh lechebnykh uchrezhdeniy p/otdela Okhrany materinstva i mladenchestva oblastnogo otdela zdravookhraneniya Nemkommuny. 1922 g. [The Report on the Conditions in Children's Hospitals of the Department of the Maternal Health and Child Health of the Area of the Germans of Volga Region. 1922]. Gosudarstvennyy istoricheskiy arkhiv nemtsev Povolzhya [State Historical Archive of the Volga Germans], F. P-851, Op. 1, D. 153.

15. Doklad p/otdela Okhrany materinstva i mladenchestva oblastnogo otdela zdravookhraneniya Nemkommuny. 1923 g. [The Report of Department of the Protection of Maternity and Infancy of the Regional Department of Health of the Area of the Germans of Volga Region. 1923]. Gosudarstvennyy istoricheskiy arkhiv nemtsev Povolzhya [State Historical Archive of the Volga Germans], F. P-851, Op. 1, D. 153.

16. Zakreplenie yasley na zimu 1933-1934 gg. [Securing Nurseries for the Winter Period of 19331934]. Gosudarstvennyy istoricheskiy arkhiv nemtsev Povolzhya [State Historical Archive of the Volga Germans], F. P-975, Op. 1, D. 233.

17. Kalinina O.S. Problemy detskogo zdorovya i gigieny u povolzhskikh nemtsev Kamyshinskogo uezda Saratovskoy gubernii v nachale XX v. [Problems of Child Health and Hygiene in the Volga Germans of Kamyshin District of Saratov Province in the early 20th Century]. Klio, 2012, no. 6(66), pp. 77-80.

18. Kolganova E.V. Zarozhdenie sistemy okhrany materinstva i mladenchestva v Rossii v nachale XX v. [Origins of Maternity and Infancy Protection System in Russia in the Early 20th Century]. Vestnik Moskovskogo universiteta. Seriya 8, Istoriya, 2011, no. 6, pp. 37-50.

19. Kotov P.P., Pilipenko V.A. Stanovlenie sistemy yaselnykh uchrezhdeniy v Komi ASSR v 1920-1930$\mathrm{kh}$ gg. [Formation of System of Nursery Facilities in the Komi Republic in 1920-1930s]. Yushkova N.A., ed. Fevralskie chteniya. Regionalnaya nauchnoprakticheskaya konferentsiya, posvyashchennaya 55-letiyu vysshego professionalnogo lesnogo obrazovaniya v Respublike Komi (Syktyvkar, 2728 fevralya 2007 g.): Sb. materialov [The collection of materials. February Readings. Regional ScientificPractical Conference Dedicated to the 55th Anniversary of Higher Professional Forestry Education in the Republic of Komi (Syktyvkar, February 27-28, 2007): Collected Materials]. Syktyvkar, 2007, pp. 253-256.

20. Petrovskiy B.V., ed. Kratkaya meditsinskaya entsiklopediya: $V 3 t$. [Brief Medical Encyclopedia: in 3 vols.]. Moscow, Sovetskaya Entsiklopediya Publ., 1989. 
21. Mokienko V.M., Nikitina T.G. Tolkovyy slovar yazyka Sovdepii [Explanatory Dictionary of the Soviet Land]. Saint Petersburg, Folio-Press, 1998. 700 p.

22. Morozova Yu.A. Zhenshchiny v obshchestvenno-politicheskoy i ekonomicheskoy zhizni nemetskoy avtonomii (1918-1941 gg.): dis. ... kand. ist. nauk [Women in Public-Political and Economic Life of German Autonomy (1918-1941). Cand. hist. sci. diss.]. Saratov, 2002. 213 p.

23. P/otdelu Okhrany materinstva i mladenchestva oblastnogo otdela zdravookhraneniya. Zaveduyushchaya detskimi yaslyami Merker. Doklad. 31 yanvarya $1922 \mathrm{~g}$. [To the Department of Protection of Maternity and Infancy of the Regional Healthcare Department. Head of the Nursery, Mrs. Merker. Report. January 31, 1922]. Gosudarstvennyy istoricheskiy arkhiv nemtsev Povolzhya [State Historical Archive of the Volga Germans], F. R-851, Op. 1, D. 105.

24. Pravila dlya materey, pomeshchayushchikh detey v yasli. 1922 g. [Rules for Mothers Who Send Their Children to a Nursery. 1922]. Gosudarstvennyy istoricheskiy arkhiv nemtsev Povolzhya [State Historical Archive of the Volga Germans], F. P-851, Op. 1, D. 153.

25. Protokol torzhestvennogo otkrytiya kursov po podgotovke rabotnikov letnikh selskikh yasel. 3 maya $1928 \mathrm{~g}$. [The Protocol of the Grand Opening of Training Courses for Employees of Summer Rural Nurseries. 3rd May 1928]. Gosudarstvennyy istoricheskiy arkhiv nemtsev Povolzhya [State Historical Archive of the Volga Germans], F. P-975, Op. 1, D. 166.

26. Rakachev V.N. Sovetskaya semya v 1920 1930-e gg.: eksperimenty v oblasti sotsialnogo konstruirovaniya [Soviet Family in 1920-1930s: Experiments in the Field of Social Construction]. Pushkareva N.L., Mitsyuk N.A., eds. Materinstvo $i$ ottsovstvo skvoz prizmu vremeni i kultur: Materialy Devyatoy mezhdunarodnoy nauchnoy konferentsii RAIZhI i IEA RAN (Smolensk, 13-16 oktyabrya 2016 g.): $v 2$ t. T. 1 [Maternity and Paternity through the Prism of Time and Culture: Proceedings of the Ninth International Scientific Conference of RAIZhI and IEA RAS (Smolensk, October 13-16, 2016). In 2 vols. Vol. 1]. Smolensk, Izd-vo SmolGU; Moscow, IEA RAN Publ., 2016, pp. 74-77.

27. Rezolyutsii i postanovleniya syezda o rabote RKP sredi rabotnits i krestyanok [Resolutions and Decisions of the Congress about the Work of Russian Communist Party among Working Women and Peasant Women]. XII syezd RKP(b) 17-25 aprelya $1923 \mathrm{~g}$. Stenograficheskiy otchet [12th Congress of Bolshevik Russian Communist Party on April 17-25, 1923. Verbatim Report]. Moscow, 1968.

28. Smirnova T.B. Etnografiya rossiyskikh nemtsev [Ethnography of the Russian Germans]. Moscow, MSNK-Press, 2012.315 p.

29. Falaleeva L.A. Deyatelnost Amerikanskoy administratsii pomoshchi na territorii Tsaritsynskoy gubernii vo vremya goloda $1920-\mathrm{kh}$ godov [The Activity of the American Aid Administration in the Territory of Tsaritsyn Province during the Famine of the 1920s]. Kurilla I.I., Rogov S.M. et al., eds. Americana. Vyp. 14. Strany Severnoy Ameriki i voyna: sb. st. [Americana. Iss. 14. North American Nations and War: Collected Articles]. Volgograd, Izd-vo VolGU, 2014, pp. 120-134.

30. Tsirkulyarno. Vsem gubernskim p/otdelam Okhrany materinstva i mladenchestva i zhenotdelam gubernskikh komitetov. 1922 g. [Circular Letter to all Provincial Departments of Protection of Maternity and Infancy, and Women's Departments of the Provincial Committees. 1922]. Gosudarstvennyy istoricheskiy arkhiv nemtsev Povolzhya [State Historical Archive of the Volga Germans], F. P-851, Op. 1, D. 93.

31. Tsirkulyarnoe pismo oblastnomu otdelu zdravookhraneniya Nemkommuny. 1923 g. [Circular Letter to the Regional Department of Healthcare of the Area of the Germans of Volga Region. 1923]. Gosudarstvennyy istoricheskiy arkhiv nemtsev Povolzhya [State Historical Archive of the Volga Germans], F. P-851, Op. 1, D. 153.

\section{Information about the Author}

Lyudmila A. Falaleeva, Assistant, Department of International Relations, Political Science and Area Studies, Volgograd State University, Prosp. Universitetsky, 100, 400062 Volgograd, Russian Federation, Ludailina25@inbox.ru,http://orcid.org/0000-0001-7724-3607.

\section{Информация об авторе}

Людмила Александровна Фалалеева, ассистент кафедры международных отношений, политологии и регионоведения, Волгоградский государственный университет, просп. Университетский, 100, 400062 г. Волгоград, Российская Федерация, Ludailina25@inbox.ru, http://orcid.org/ 0000-0001-7724-3607. 